Valóságos könyvtár - könyvtári valóság. Könyvtár- és információtudományi tanulmányok 2020. Szerk. Kiszl Péter, Boda Gáborné Köntös Nelli.

Budapest, ELTE BTK Könyvtár- és Információtudományi Intézet. 2021. 421-427.

\title{
A KÖZ- ÉS ISKOLAI KÖNYVTÁRAK OKTATÁSI ÉS NEVELÉSI SZEREPÉNEK ERŐSÖDÉSE SZEMLE A HAZAI ÉS NEMZETKÖZI SZERVEZETEK IRÁNYMUTATÁSAIBÓL
}

\author{
ARANY-NAGY ZSUZSANNA \\ Budapest IX. Kerületi Szent-Györgyi Albert Általános Iskola és Gimnázium, \\ könyvtáros
}

\section{TARTALMI ÖSSZEFOGLALÓ}

A tudásalapú társadalomban a könyvtáraknak igen nagy elvárásoknak kell megfelelniük, hiszen egyre távolabb kerülnek hagyományos szerepüktől. Napjainkban sokkal fontosabbá válik az információk távoli elérése. A könyvtár funkciója ezáltal átalakul, ugyanis sokkal nagyobb igény van az úgynevezett közösségi tér funkciók, és a helyhez kötött információk tárolása és szolgáltatása mellett a digitális írástudás, az információs műveltség fejlesztését célzó könyvtári foglalkozások, rendezvények szervezésére, valamint oktatási feladatok ellátására.

A közkönyvtárak és az iskolai könyvtárak tevékenysége alkalmas a könyv- és könyvtárhasználattal kapcsolatos motivációra, a személyes elköteleződés növelésére, a könyvtári képzések hatékonyságának javítására, a potenciális új olvasók megszólítására és más könyvtári rendezvények népszerüsítésére is.

A tanulmány a köz- és iskolai könyvtárak oktatási tevékenységének lehetőségeire, fontosságuk bemutatására fókuszál, olyan nemzetközi szervezetek útmutatóit, ajánlásait áttekintve, mint az IFLA, az UNESCO, az ALA és az AASL. Az említett szervezetek által kiadott irányelvek azokra az elvárásokra hívják fel a figyelmet, amelyeknek az egyes könyvtártípusoknak meg kell felelniük.

\section{Bevezetés}

A könyvtár funkciója, hagyományos használata napjainkban átalakul, ugyanis sokkal nagyobb igény van ún. közösségi tér funkciók, valamint a helyhez kötött információk tárolása- és szolgáltatása mellett a digitális írástudás, az információs műveltség fejlesztését célzó könyvtári foglalkozások, olvasásnépszerűsítő rendezvények szervezésére, valamint oktatási tevékenység ellátására. A könyvtárak társadalmunkban betöltött szerepe ezzel párhuzamosan indul változásnak. Célul tűzték ki az információs egyenlőséget, az oktatás támogatását, a kultúraközvetítést és a rekreációs lehetőségek biztosítását. ${ }^{1}$

A könyvtárakban az oktatási tevékenység szervezése és lebonyolítása korántsem újkeletű dolog. Több nemzetközi szakmai szervezet, a Könyvtári Egyesületek és Szervežetek. 


\section{ARANY-NAGY ZSUZSANNA}

Nemzetközi Szövetsége (International Federation of Library Association = IFLA), az Amerikai Könyvtári Szövetség (American Library Association = ALA), az Amerikai Könyvtárostanárok. [1skolakönyvtárosok] Szövetsége (American Association of School Librarians = AASL) vagy az Egyesült Nemzetek. Nevelésügyi, Tudományos és Kulturális Szervezete (United Nations Educational, Scientific and Cultural Organization = UNESCO) is foglalkozik a közkönyvtárak, iskolai könyvtárak és más könyvtártípusok oktatási tevékenységével. Ezek a szervezetek keretrendszereket határoznak meg és javaslatokat tesznek, iránymutatást adnak a könyvtárosok és a használók (tanulók) számára az oktatás hatékony megvalósítása érdekében. Hazánkban a Magyar Könyvtárosok Egyesülete (MKE) és a Könyvtárostanárok Egyesülete (KTE) fogja össze a köz- és iskolai könyvtárakban dolgozó könyvtárosokat.

Az információs múveltség, a digitális írástudás fejlesztését, valamint a kritikus és etikus forráshasználat tanítását már kisiskolás korban el kell kezdeni, ezért fontos kiemelni az iskolai könyvtárak és a szakképzett könyvtárostanárok nevelési-oktatási tevékenységét. Hazai és nemzetközi szervezetek foglalkoznak a témával, iránymutatásokat, javaslatokat tartalmazó dokumentumokat adnak ki.

E két könyvtártípus tevékenységében kiemelt szerepű az oktatás, a felhasználóképzés, az olvasóvá nevelés. A Könyvtári Intézet által közzétett statisztikai adatokból megállapítható, hogy 2018-ban az iskolai könyvtárak száma $(4280)^{2}$ meghaladta a regisztrált egyéb könyvtártípusba tartozó könyvtárak $(3940)^{3}$ számát, alátámasztva, hogy a hazai iskolai könyvtárak jelentős részét képezik a könyvtári rendszernek, így oktatási munkájuk is nagy hatással lehet a digitális kor nemzedékeire.

Tanulmányomban összegzem a közkönyvtárak és az iskolai könyvtárak nevelési, oktatási tevékenységének jellemzőit, valamint a felhasználóképzésben és az olvasóvá nevelésben betöltött szerepüket az említett hazai és nemzetközi szervezetek által kiadott dokumentumok áttekintésével.

\section{A közkönyvtárak}

Magyar fordításban a Könyvtári Intézet gondozásában jelent meg az IFLA és az UNESCO közkönyvtárakra vonatkozó irányelveit tartalmazó dokumentuma. A dokumentumban meghatározták a közkönyvtár fogalmát, valamint elsődleges céljait is: „A közkönyvtár elsödleges célja, hogy változatos hordozókon megjelenö forrásokekal és szolgáltatásokekal elégitse ki az. egyének és csoportok tanulmányi, információs és önmegvalósitásuk.kal kapcsolatos igényeit, beleértve a szórakozást és kikapcsolódást is." "4

A dokumentum 1.3.1. fejezete a közkönyvtárak oktatási tevékenységének leírását és az arra vonatkozó ajánlásokat tartalmazza. Az IFLA és az UNESCO 1994-es közkönyvtári nyilatkozatában olvasható az alábbi mondat: „támogatja az egyéni és az önállóan folytatott tanulmányokat, valamint az iskolarendszerü oktatás minden szintjét." ". Az információboz. valo hozzáférés és az eredményes információhasználat lényeges a sikeres tanulmányok szempontjából, 
ezért ahol csak lehetséges, a közkönyvtáraknak kooperálniuk kell más oktatási szuervez̨etekeel az. információs források használatának megtanitásában."

Az információforrások használatának tanítása, az információkeresési stratégiák elsajátíttatása - ha már kooperációról beszélünk - számos kreatív módon is megvalósulhat. Példákat találhatunk ennek támogatására a Könyvtárostanárok Egyesületének gondozásában rendszeresen megjelenő Kis KTE Könyvek sorozat egyes részeiben, például a 2017ben megjelent 9. kötetben, amely a Könyvtárhasználati ötlettár: játékos feladatok ${ }^{7}$ címet viseli.

Az IFLA és az UNESCO már említett, 2005-ben megjelent dokumentumán kívül több más nemzetközi és regionális szabályozást, iránymutatást is találunk, amelyek a könyvtárakra, iskolai könyvtárakra vetítve uniformizálják azok céljait, értékeit, valamint a követelményeket, amelyeket a XXI. századi tudástársadalom támaszt a különböző típusú intézményekkel szemben. Érdemes még megemlíteni egy 2016-os dokumentumot, amelyet az ausztrál könyvtárak számára adtak közre, és szabványokat, irányelveket fogalmaz meg a közkönyvtárak számára. ${ }^{8}$ Rövid bevezetés és az ausztrál közkönyvtári rendszer áttekintése után következnek az egyes szabványok és irányelvek (pl. a könyvtári menedzsmenttel, személyzettel, gyújteményekkel kapcsolatban). A dokumentum deklarálja, hogy az ausztrál közkönyvtárak támogatják és kiszolgálják a helyi közösségek információs, oktatási, kulturális és rekreációs igényeit. Alapelvük az információs forrásokhoz, oktatási eszközökhöz való hozzáférés biztosítása, valamint az infokommunikációs technológiák és könyvtári források használatának oktatása. A kiadványból megismerhetjük az ausztrál közkönyvtárak folyamatos tanulástámogatási tevékenységét, amelyet kiterjesztettek nemcsak a felhasználókra, hanem a munkatársaikra is. A XXI. századi elvárásokhoz igazodva igyekeznek lehetőséget adni az élethosszig tartó tanulásra és támogatják is azokat, akik erre fogékonyak. Az általuk szervezett oktatási programok között hangsúlyosak az információs múveltség, a digitális írástudás, a médiamúveltség és a kritikai gondolkodás fejlesztését célzó rendezvények, amelyek hatással vannak az olvasói aktivitás növekedésére is.

\section{Az iskolai könyvtárak}

"Az iskolai könyvtár mindenki számára a tanitás és tanulás színhelye." Ezzel a mondattal kezdődik az IFLA és az UNESCO közös kiadásában megjelent, az UNESCO Közgyűlés által 1999-ben elfogadott iskolai könyvtári nyilatkozat. A nyilatkozat kitér az iskolai könyvtárak missziójára, meghatározza a feladatait, beszél az oktatás támogatásáról, a megőrzés, feltárás és szolgáltatás hármasáról, amely minden könyvtártípusnak - beleértve az iskolai könyvtárakat is - alapfeladata. Kiemeli, hogy az iskolai könyvtáraknak többszintű együttmúködést szükséges ápolniuk az iskola tanári karával és vezetőségével. Elengedhetetlen, hogy a könyvtári rendszerben is elfoglalja a helyét, biztosítva ezzel felhasználói számára a szükséges információkat, dokumentumokat. Az iskolai könyvtárak mintegy hídszerepet töltenek be az olvasóvá nevelés, valamint a szövegértés fejlesztése terén. Képletesen szólva 


\section{ARANY-NAGY ZSUZSANNA}

„félúton” helyezkednek el a tanterem és az otthon falai között, biztosítva ezzel a lehetőséget a tanórai és tanórán kívüli keretek között történő tanulásra, információszerzésre.

A Könyvtári Egyesületek Nemzetközi Szövetsége (IFLA) 2015-ben adta ki Barbara Schultz-Jones és Dianne Oberg szerkesztésében az IFLA Iskolai könyvtári útmutató című dokumentum 2. javított kiadását, amelynek magyar fordítását egy évvel később a Könyvtárostanárok Egyesületének köszönhetjük. A 2016 óta magyar nyelven is elérhető dokumentum - a közkönyvtári irányelveket megfogalmazó dokumentumhoz hasonlóan - részletesen tárgyalja az iskolai könyvtárak küldetését és céljait, múködésük jogi, gazdasági hátterét, az emberi, digitális és fizikai erőforrásait, az iskolai könyvtári programokat, valamint a közönségkapcsolati tevékenységeit. Ahogyan Barbara SchultzJones és Dianne Oberg szerkesztők az előszóban megfogalmazták: „Ez az útmutató azért készült, hogy támogassa az iskolai könyvtáros szakembereket és az oktatási döntéshozókat abban az eröfeszitésükben, hogy gondoskodjanak arról, hogy minden diák és tanár hozzájusson olyan hatékony iskolai könyvtári szolgáltatásokhoz és programokhoz, amelyeket képzett iskolai könyvtárosok nyújtanak számukra." ${ }^{10} \mathrm{Az}$ útmutató megfogalmazza, hogy „az iskolai könyvtárak az egész. világon olyan tanulási környezetként müködnek, amely bižtositja a fizikeai és digitális helyszint, hozzáférést a forrásokhoz, a tevékenységekhez, a szolgáltatásokhoz, ezáltal segitve, támogatva a diákokat, tanárokat és az egész tanulási kööösséget."11 A dokumentum szól az iskolai könyvtárak iskolán belüli szerepérôl, amely szerint a tantervekbe integrálva kell aktív oktatási programokat biztosítani a diákok forráshasználati készségeinek, kritikai gondolkodásának, információs műveltségének, digitális írástudásuk, olvasási-, szövegértési- és íráskészségük, továbbá szociális- és tanulási készségeik fejlesztésére. Ezeket a könyvtár tanórai és tanítási időn túli foglalkozások segítségével is megvalósíthatja, ügyelve arra, hogy módszertanában igazodjon a XXI. századi elvárásokhoz.

A dokumentumban 16 ajánlást fogalmaztak meg a könyvtárosok és iskolai könyvtári döntéshozók számára, az iskolai könyvtár cél- és küldetésrendszerérôl, tevékenységének ellenőrzéséről, értékeléséről és szabályozásáról az állományára, kapcsolati hálójának kialakítására, munkatársainak kompetenciáira, valamint szervezett programjaira vonatkozóan.

Készültek regionális szabályozások, útmutatások is. Említésre érdemes Texas állam iskolai könyvtári programja, amelyet 2017-ben fogadtak el. A programban nagy hangsúlyt fektetnek a XXI. századi kompetenciák (digitális írástudás, információs múveltség) fejlesztésére. Nagy szerepet kap a digitális tanulási környezet kialakítása és használata is. Helyet kapnak olyan napjainkban teret hódító, új oktatási módszerek is, mint például a kutatásalapú (vagy felfedezésalapú) tanulás (inquiry-based learning). Az olvasásnépszerűsítés mellett kiemelt jelentőségű a dokumentumban a biztonságos és gondoskodó környezet ${ }^{12}$ kialakításáról szóló fejezet.

Az iskolai könyvtárak tevékenysége magabiztosan illeszkedik a XX. század végén létrejött új paradigmába, amely gyökeres változásokat hozott a pedagógiában. „A konstruktivista tanulás felfogása szerint a tanulás egy belsö konstrukció eredménye, azaz a tanuló a tudást saját maga épiti fel saját belsö folyamatai által. [...] Az elözetes tudásnak segitségével értelmezi az üj 
ismereteket, amelyekhez kapcsolja, majd rögzíti az üjakat. Az irányzat szerint [...] megfelelö tanulási környezetet kell létrehozni a tanulók számára ehhez a [...] folyamathoz:"13 A konstruktivista pedagógia elméletébe remekül beleilleszkedik az inquiry based learning módszertana. A felfedezésalapú tanulás egyik legmegfelelőbb színtere az iskolai könyvtár lehet, ahol a diákok szabadon kutathatnak a számukra rendelkezésre álló állományban, adatbázisokban.

\section{Hatékony módszerek és eszközök a könyvtárak oktatási és olvasásnépszerüsitö tevékenységében}

Számos olyan eszközt, módszert ismerünk, amely a könyvtár- és olvasásnépszerūsítésben hatékonyan alkalmazható. A felhasználók szívesen járnak író-olvasó találkozókra és más könyvtári rendezvényekre. Jó irányba fejlődik a könyvtárról alkotott képük, ha a rendezvényeknek köszönhetően olyan élményeket kapnak, amelyekre pozitívan tekintenek vissza. A következőkben három olyan módszert és eszközt mutatok be, amelyek hatékonyan alkalmazhatók könyvtári környezetben is.

Az egyik ilyen lehetőség a könyvtárak számára olvasókörök szervezése. Béres Judit ${ }^{4}$ összefoglalójában az olvasókörök célrendszeréről ír. Megfogalmazza, hogy az olvasókör „az informális és interperszonális tanulás egyike lehetséges és fontos helye, abol a legkëulönbözóbb életkorú, hátterü és érdeklódésü emberek találkozhatnakés oszthatják meg egymással a közös olvasmányhoz. kapcsolódó érzéseiket, gondolataikat." ${ }^{15}$ Az olvasókör egy „,szellemileg inspiráló légkeör"16, amely teret ad a saját vélemény kifejtésére. Célja a közös olvasmányok elemzésén keresztül a csoport tagjai ismereteinek bővítése, műveltségük, önismeretük indirekt módon történő fejlesztése. A módszer sajátossága, hogy bármely korosztálynál alkalmazható.

Hosszabb távú, többnapos olvasásnépszerűsítő program keretében a könyvtáraknak lehetőségük van olvasótáborok szervezésére, ahogy ezt Gombos Péter ${ }^{17}$ is kifejti. Többféle olvasótábor szervezhető, a legfontosabb azonban, hogy a foglalkozások vezetője minden esetben pedagógiai gyakorlattal rendelkező személy legyen, aki, ha szükséges, képes rögtönözni. Az olvasótáborokban számos pedagógiai módszer segítségül hívható a kooperatív tanulásszervezéstől kezdve a csoportmunkán át a drámapedagógia eszköztáráig.

Könyvtárostanárként, pedagógusként figyelmet szentelek a játékosítás módszerének. A téma hazai és külföldi szakirodalma az utóbbi években vált népszerúvé. Noha a módszer elsődlegesen az üzleti szférából indult útjára, a pedagógiában is egyre nagyobb teret igyekszik meghódítani, így érdemes lehet ezt a későbbiekben a könyvtárak aspektusából is megvizsgálni.

\section{Összegzés}

Írásomban olyan hazai és nemzetközi szervezetek által jegyzett iránymutatásokról szóltam, amelyek a könyvtárak céljait fogalmazzák meg és a múködésüket segítik. Ajánlások, jó gyakorlatok és megvalósult programok széles választéka áll rendelkezésünkre. 


\section{ARANY-NAGY ZSUZSANNA}

A bemutatott dokumentumok azért jöttek létre, hogy segítsék a könyvtárakat és könyvtárosokat a XXI. század társadalmának való megfelelésben, az élethosszig tartó tanulás támogatásában, vagy akár az információs műveltség fejlesztésében való részvételükben.

A könyvtárak oktatási tevékenységének központjába az információs múveltség, a digitális írástudás, a médiaműveltség fejlesztését célzó programokat kell helyezniük, legyen szó bármely korosztályról. Ismerünk olyan programokat, amelyek IKT használatot tanítanak idôsebb generációknak, de tudomásunk van ifjakat megcélzó író-olvasó találkozók szervezéséről, amelyek célja az olvasás népszerűsítése. Nem ritka az olvasótáborok, könyvklubok (kvízestek, vetélkedők) szervezése, nem is szólva az elmúlt években egyre népszerűbbé váló Múzeumok Éjszakája vagy a Könyvtári Éjszaka nevű rendezvényekről. A könyvtárak közösségi térként is funkcionálnak, teret biztosítva a közös tanuláshoz és az önálló, csendes kutatáshoz is. A közösségi tér funkciók és a könyvtári közösségépítés erôsítésére hozták létre a különböző játékesteket, amelyek az elmúlt évek tapasztalatai alapján egyre nagyobb látogatói létszámnak örvendenek.

Az iskolai könyvtárak szerepvállalása - szakképzett iskolai könyvtárosok, könyvtárostanárok segítségével - a fent említett XXI. századi készségek fejlesztésében, ismeretek bővítésében nem elhanyagolható. Egy-egy jól felszerelt iskolai könyvtár kiváló tere a formális és informális keretek között megvalósuló tanulásnak. Az iskolai könyvtárak nagyban hozzájárulnak a konstruktivista pedagógia, valamint a felfedezésalapú tanulás támogatásához, az olvasásnépszerűsítéséhez és az olvasóvá neveléshez.

\section{Jegyzetek és irodalom}

1. TÓTH Máté: Új típusú együttmúködések. In: Béres Judit (szerk.): A könyvtárhasználat és az információkeresés fejlesztése. Budapest, Fővárosi Szabó Ervin Könyvtár, 2019. 317-345. p.

2. Könyvtári Intézet: A magyarországi iskolai könyvtárak statisztikai adatai és mutatói 1947/ 1948-. Forrás: https://ki.oszk.hu/dokumentumtar/magyarorszagi-iskolai-konyvtarak-statisztikai-adatai-es-mutatoi-19471948-statistical [2020. február 25.]

3. Könyvtári Intézet: Minden könyvtár minden adata. Forrás: https://ki.oszk.hu/dokumentumtar/minden-konyvtar-minden-adata-2018 [2020. február 25.]

4. GILL, Philip: A közkönyvtári szolgálat: az IFLA és az UNESCO fejlesztési irányelvei. Budapest, Könyvtári Intézet, 2005. 15. p.

5. Uo.

6. Uo.

7. BOGYÓ Katalin, Cs. - DÖMSÖDY Andrea (szerk.): Könyvtárhasználati ötlettár: játékos feladatok. Budapest, Könyvtárostanárok Egyesülete, 2017.

8. Guidelines, standards and outcome measures for australian public libraries. Canberra ACT, Australian Library and Information Association, 2016. Forrás: https://www.alia.org.au/ sites/default/files/Guidelines $\% 20$ Standards $\% 20$ and $\% 20$ Outcome $\% 20$ Measures $\% 20$ for $\% 20$ Australian $\% 20$ Public $\% 20$ Libraries.pdf [2020. február 26.] 
9. Az IFLA és az UNESCO közös iskolai könyvtári nyilatkozata. 1999. Forrás: https:// www.ifla.org/files/assets/school-libraries-resource-centers/publications/school-librarymanifesto-hu.pdf [2020. február 24.]

10. SCHULTZ-JONES, Barbara - OBERG, Dianne (ed.): Iskolai könyvtári útmutató. Hága, IFLA, 2015. 5. p.

11. Uo.

12. School library programs: standards and guidelines for Texas. Austin, Texas State Library and Archives Commissionand, Texas Education Agency, 2017. Forrás: https://www.tsl. texas.gov/sites/default/files/public/tslac/ld/schoollibs/costforstandards/Texas $\% 20$ School\%20Library\%20Standards\%20E-Version\%20FINAL.pdf [2020. február 26.]

13. TÓTH Viktória: A köznevelés és könyvtárai - az iskolai könyvtárak. Az iskolai könyvtárak hídszerepe a szövegértés fejlesztésében. In: Barátné Hajdu Ágnes - Béres Judit (szerk.): Szövegértés-fejlesztés a könyvtárban. Budapest, Fővárosi Szabó Ervin Könyvtár, 2019. 281. p.

14. BÉRES Judit: Olvasókör. In: Barátné Hajdu Ágnes - Béres Judit (szerk.): Olvasásfejlesztés könyvtári környezetben. Budapest, Fővárosi Szabó Ervin Könyvtár, 2019. 12-13. p.

15. Uo.

16. Uo.

17. GOMBOS Péter: Olvasótábor. In: Barátné Hajdu Ágnes - Béres Judit (szerk.): Olvasásfejlesztés könyvtári környezetben. Budapest, Fővárosi Szabó Ervin Könyvtár, 2019. 13-15. p.

Arany-Nagy Zsuzsanna - a Budapest IX. Kerületi Szent-Györgyi Albert Általános Iskola és Gimnázium könyvtárosa, valamint az ELTE BTK Irodalomtudományi Doktori Iskola Könyvtártudományi Doktori Programjának doktorandusz hallgatója. Tagja a Magyar Könyvtárosok Egyesületének és a Könyvtárostanárok Egyesületének. 2019-ben neki itélték Az év igéretes könyvtárostanára címet. Kutatási területe: az iskolai könyvtárak szerepvállalása a közoktatásban. 